Georgetown University Law Center

Scholarship @ GEORGETOWN LAW

2018

\title{
A Hiatus in Soft-Power Administrative Law: The Case of Medicaid Eligibility Waivers
}

David A. Super

Georgetown University, das62@law.georgetown.edu

This paper can be downloaded free of charge from:

https://scholarship.law.georgetown.edu/facpub/2045

https://ssrn.com/abstract=3148176

65 UCLA L. Rev. 1590 (2018)

This open-access article is brought to you by the Georgetown Law Library. Posted with permission of the author.

Follow this and additional works at: https://scholarship.law.georgetown.edu/facpub

Part of the Administrative Law Commons 


\title{
U.C.L.A. Law Review
}

\section{A Hiatus in Soft-Power Administrative Law: The Case of Medicaid Eligibility Waivers}

\author{
David A. Super
}

\begin{abstract}
Administrative law is fundamentally a regime of soft power. Congress, the President, administrative agencies, civil servants, and the courts all operate within a broad consensus for rational, goodfaith decisionmaking. Congress grants agencies discretion, and courts and civil servants defer to agencies' political leadership based largely on the expectation that the latter are seeking to honor statutes' purposes. That expectation of prudential restraint also allays concerns about delegations of legislative power. When the executive systematically disregards that expectation and seeks singlemindedly to maximize achievement of its policy objectives, deference's justification breaks down.
\end{abstract}

Across agencies, the Trump administration has disregarded the assumptions on which administrative law's soft power consensus depends. Its waivers allowing states to deny Medicaid to otherwise eligible low-income people unable to find employment exemplifies this disregard. Exploiting a sweeping delegation of authority to test new ways to achieve Medicaid's goal of providing health care coverage, this administration has instead sought to achieve very different goals, from legislation that Congress has rejected. The waiver applications themselves estimate substantial increases in the numbers of uninsured people.

Ignoring the administration's disregard of the longstanding administrative law consensus could deter future Congresses from valuable delegations of discretion. Permanently abandoning the deferential soft-power model would seriously undermine future governance. Instead, courts and civil servants should treat this period as a hiatus in consensus for good-faith decisionmaking. Courts should suspend deference and other aspects of soft-power jurisprudence. And civil servants should comply with political officials' lawful directions but should remain steadfastly truthful in their words and actions.

\section{AUTHOR}

Professor of Law, Georgetown University. The author is grateful to Jon Michaels and the other participants in the UCLA Law Review Symposium for their helpful comments, and to Stefan Love and Sarah Rahimi for superb editing. 


\section{TABLE OF CONTENTS}

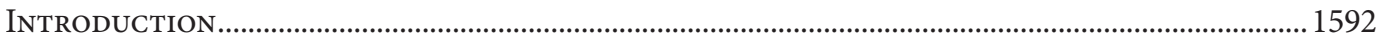

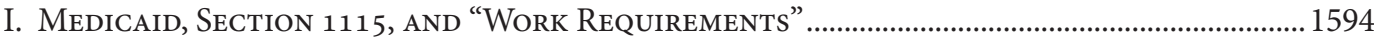

A. Section 1115: "Demonstration Project" Authority …………....................................................... 1595

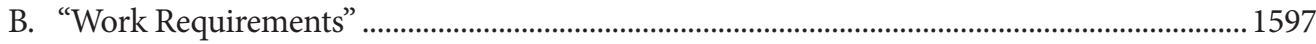

C. Legal Problems With the Administration's Waivers .................................................................... 1599

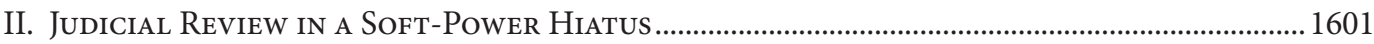

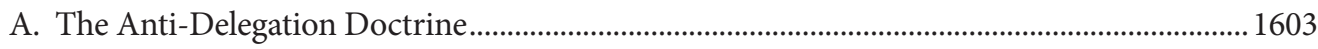

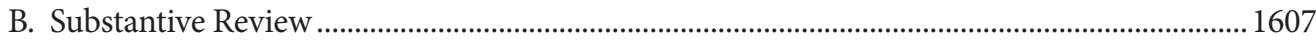

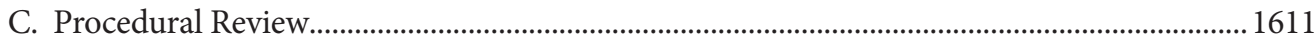

III. The Civil Service in A Soft-Power Hiatus ........................................................................... 1613

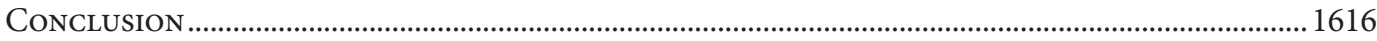




\section{INTRODUCTION}

Administrative law, more than any other branch of public law, has always been characterized by a delicate mix of hard and soft power. Political appointees can overrule career staff, but the system makes that cumbersome, and they rarely do. Though career staff can substitute their own policy preferences for those of their agencies' political leaders, the system makes that difficult, and they rarely do. And Congress can override agencies' interpretations of statutes, but scarce resources make that difficult, and it rarely does.

Courts, too, have developed a nuanced approach toward exercising soft power to vindicate important norms. To be sure, courts have maintained a formidable arsenal of hard-power weapons, but they make a point of rarely using them. Many of the most celebrated administrative law cases involve courts deferring to the substantive or procedural judgments of agencies. Even in those relatively rare cases in which courts do interfere with an agency's actions, the Court has made a point of not precluding the agency from persisting in its chosen course. For example, the Court rejected the SEC's first foray against the Chenerys, ${ }^{1}$ but it carefully left the door open for future agency sanctions on a different theory. The Court then demonstrated that this really was a soft-power regime when it affirmed the SEC's actions after the case came up a second time. ${ }^{2}$ For their part, agencies typically take the hint: For example, although the Court did not construe federal statutes as prohibiting highway construction through Overton Park, ${ }^{3}$ its strong skepticism was enough to get the Department of Transportation to change course. ${ }^{4}$

The maintenance of a soft-power regime of administrative law depends on broad structural consensus. Career staff must accept the legitimacy of political appointees; political appointees must assume that career civil servants will take seriously their directions, subject to constraints of law and feasibility but not personal ideological disagreement; and courts must believe that agencies' actions reflect the considered judgment of career officials making good-faith efforts to follow the law.

1. SEC v. Chenery Corp., 318 U.S. 80, 95 (1943).

2. SEC v. Chenery Corp., 332 U.S. 194, 209 (1947).

3. Citizens to Preserve Overton Park, Inc. v. Volpe, 401 U.S. 402, 413 (1971).

4. See Citizens to Preserve Overton Park, Inc. v. Brinegar, 494 F.2d 1212 (6th Cir. 1974) (affirming agency's subsequent rejection of road). 
In several ways, this structural consensus depends significantly on the repetitive nature of administrative law interactions. Career staff know that, over time, they will have to work with political appointees of both parties; their success and longevity depends on being perceived as honest brokers by whomever the political process sends their way. In addition, when they find particular appointees' guidance distasteful, they can look forward to new political masters whose preferences are more to their liking. Congress refrains from overturning every action it dislikes because it does not want to demoralize agencies it needs to carry out its initiatives in other areas. Courts assume that agencies will not act outlandishly lest they damage their reputations and imperil their chances in inevitable future litigation on other issues.

It follows, then, that when this structural consensus frays, the soft-power regime of administrative law will become unworkable. This is particularly true when key actors cease to be, or cease to regard themselves as, long-term repeat players. Instead of a heavily iterated prisoner's dilemma, in which rational players will quickly begin to cooperate, we move to individual games, in which the incentives to defect are quite powerful.

This Article argues that we have entered such a period of dissensus about the structure of the administrative state. The Trump administration, in word and deed, has rejected the broad structural consensus about the means and limits of administrative law that have existed since the New Deal. Perhaps even more crucially, the administration has acted and seemed to act in ways that are temporally discontinuous from its predecessors and from any successors that do not share its policy views. This president is often sharply estranged from much of his own party, has faced catastrophic polling since his early days in office, and is under an investigation that threatens his ability to serve out his term. He has faced unprecedented turnover among his political appointees. ${ }^{5}$ Only the naïve would believe that his administration expects sufficient repeat interactions with other important actors to constrain its behavior. Moreover, high-level officials have bragged about their insubordination to journalists and, in an anonymous op-ed, have suggested a total breakdown of crucial

5. Kathryn Dunn Tenpas, Why Is Trump's Staff Turnover Higher Than the 5 Most Recent Presidents?, BROOKINGS INST. (Jan. 19, 2018), https://www.brookings.edu/research/why-istrumps-staff-turnover-higher-than-the-5-most-recent-presidents [https://perma.cc/Q2D3-8FBT]. 
assumptions of deference and respect for the rule of law within the administration. ${ }^{6}$

This collapse in structural consensus requires a suspension, although not a termination, of the soft-power model of administrative law. In particular, the two main institutional guardians of administrative legality and continuity-the courts and career civil servants-can and should adopt a far less deferential approach to this administration's actions of questionable legality. Fortunately, our system of administrative law provides ample means both for responding to this extraordinary situation while it lasts and for returning to the soft-power regime of administrative law when the emergency passes. This course is far superior to either ignoring the current administration's fundamental discontinuity from its predecessors, on the one hand, or making permanent changes to a basically sound regime of administrative law, on the other.

To make this argument more concrete, this Article focuses on one of the many exceptional actions this administration has taken: using the Social Security Act's section 1115 "demonstration project" authority to encourage states to impose "work requirements" on Medicaid recipients. This Article begins with a brief description of this action and the questions concerning its legality. It then moves on to consider the tools available to the judiciary to check this action. From here, it assesses how civil servants might plausibly respond. Finally, it looks ahead to how various possible responses will position administrative law when the present conditions pass.

\section{MEDICAID, SECTION 1115, AND “WORK REQUIREMENTS"}

The Medicaid statute does not allow otherwise eligible people to be denied coverage for noncompliance with work requirements in most circumstances ${ }^{7}$ and prohibits both federal and state agencies from narrowing statutory eligibility criteria. ${ }^{8}$ On January 11, 2018, however, the Trump administration released policy guidance announcing its receptivity to states' requests for

6. Philip Rucker et al., 'The Sleeper Cells Have Awoken': Trump and Aides Shaken by 'Resistance' Op-Ed, WASH. POST, (Sept. 5, 2018), https://www.washingtonpost.com/ politics/the-sleeper-cells-have-awoken-trump-and-aides-shaken-by-resistance-oped/2018/09/05/ecdf423c-b14b-11e8-a20b-5f4f84429666_story.html?utm_term=.bb76fefb74c0 [https://perma.cc/7C53-53KS].

7. See 42 U.S.C. $\$ 1396 u-1(b)(3)$ (2012) (allowing states to terminate Medicaid only for adults whose TNAF-funded cash assistance is terminated for violation of work rules).

8. See id. $\$ 1396 \mathrm{a}(\mathrm{a})(8)$ (requiring provision of Medicaid with reasonable promptness to all applicants meeting federal eligibility criteria); King v. Smith, 392 U.S. 309 (1968) (interpreting similar language in former Aid to Families with Dependent Children statute as barring states from adding eligibility conditions). 
waivers to impose "work requirements" on Medicaid recipients. ${ }^{9}$ The next day, it approved the first such waiver for Kentucky. ${ }^{10}$ It subsequently approved similar ones for Indiana, ${ }^{11}$ Arkansas, ${ }^{12}$ and New Hampshire. ${ }^{13}$ It has at least eight more pending. ${ }^{14}$

\section{A. Section 1115: "Demonstration Project" Authority}

Congress added section $1115^{15}$ to the Social Security Act in $1962 .{ }^{16}$ Subsection (a)(1) provides that for "any experimental, pilot, or demonstration project which, in the judgment of the Secretary, is likely to assist in promoting the objectives of [the Act's cash assistance, child support enforcement, or Medicaid titles] in a State or States ... the Secretary may waive compliance with any of the requirements of [many of the eligibility-creating sections of those titles], as the case may be, to the extent and for the period he finds necessary to enable such State or States to carry out such project." Section 1115(a)(2) also allows states to claim federal matching funds for expenditures on these projects that would not otherwise qualify under programmatic rules. The resulting policy changes are commonly termed " 1115 waivers."

9. Letter From Brian Neale, Dir., Dep't of Health \& Human Servs., Ctrs. for Medicare \& Medicaid Servs., to State Medicaid Dirs. (Jan. 11, 2018), https://www.medicaid.gov/ federal-policy-guidance/downloads/smd18002.pdf [https://perma.cc/V7GP-HSUK].

10. Letter From Brian Neale, Deputy Adm'r, Ctr. for Medicaid \& CHIP Servs., to Adam Meier, Deputy Chief of Staff, Office of Governor Matthew Bevin (Jan. 12, 2018), https://kaiserhealthnews.files.wordpress.com/2018/01/kentucky-1115-memo-andapproval-ltr.pdf [https://perma.cc/PVK8-GGWW].

11. Press Release, Dep't of Health \& Human Servs., HHS Approves New Healthy Indiana Medicaid Demonstration (Feb. 2, 2018), https://www.hhs.gov/about/news/2018/02/02/ hhs-approves-new-healthy-indiana-medicaid-demonstration.html [https://perma.cc/CX7BHTYM].

12. Letter From Seema Verma, Adm'r, Ctrs. for Medicare \& Medicaid Servs., to Asa Hutchinson, Governor of Ark. (Mar. 5, 2018), https://www.medicaid.gov/MedicaidCHIP-Program-Information/By-Topics/Waivers/1115/downloads/ar/ar-works-ca.pdf [https://perma.cc/7QEH-86ZF].

13. Letter From Seema Verma, Adm'r, Ctrs. for Medicare and Medicaid Servs., to Henry D. Lipman, Medicaid Dir., N.H. Dep't of Health \& Human Servs. (May 7, 2018), https://www.medicaid.gov/Medicaid-CHIP-Program-Information/By-Topics/Waivers/ 1115/downloads/nh/nh-health-protection-program-premium-assistance-ca.pdf [https://perma.cc/S5YY-AS8P].

14. Medicaid Waiver Tracker: Which States Have Approved and Pending Section 1115 Medicaid Waivers?, KAISER FAM. FOUND. (June 27, 2018), https://www.kff.org/medicaid/ issue-brief/which-states-have-approved-and-pending-section-1115-medicaid-waivers [https://perma.cc/2NX4-UEBE].

15. 42 U.S.C. $\$ 1315$ (2012).

16. Public Welfare Amendments of 1962, Pub. L. No. 87-543, $\$ 122,76$ Stat. 172, 192 (codified as amended in scattered sections of 42 U.S.C.). 
Wilbur Cohen, Secretary of Health, Education, and Welfare at the time of this section's enactment, described it as a minor administrative provision that would facilitate research. ${ }^{17}$ For its first quarter century, that is all it was. A state might, for example, test the effects of a different benefit calculation formula on work incentives or of making payments directly to landlords (rather than directly to households) on eviction rates. Researchers would analyze the project's results, with particularly promising ones giving rise to proposals to Congress or the federal agency for policy changes.

Late in the Reagan administration, however, some enterprising White House officials recognized section 1115's potential to allow states to change the Aid to Families with Dependent Children (AFDC) program in ways the Democratic Congress was unlikely to approve. These 1115 waivers sometimes operated statewide; the policies they implemented, such as harsher penalties for families with very young children, were not so much ones whose impact was unknown as ones for which no national political consensus existed. The George H. W. Bush administration continued and expanded section 1115's role in circumventing recipient protections in the AFDC statute. ${ }^{18}$ President Clinton, having campaigned on "welfare reform" but having great difficulty crafting legislation that reconciled his various promises, felt unable to restrict the availability of waivers and indeed hoped they could buy off disgruntled governors who were pressing for enactment of Republican welfare bills. By the time the Personal Responsibility and Work Opportunity Reconciliation Act of $1996^{19}$ repealed AFDC, the program's rules were still in effect in a shrinking minority of states. ${ }^{20}$

Several administrations relied on 1115 waivers to promote Medicaid managed care. ${ }^{21}$ The George W. Bush administration encouraged states to seek 1115 waivers to subsidize employer-sponsored coverage for low wage workers, to expand pharmaceutical coverage for the elderly, and to narrow benefits to fund expanded coverage. The Obama administration briefly explored granting 1115 waivers to expand the range of activities that could meet cash assistance

17. See Wilbur J. Cohen \& Robert M. Ball, The Public Welfare Amendments of 1962, 20 PuB. WELFARE 191 (1962).

18. Susan Bennett \& Kathleen A. Sullivan, Disentitling the Poor: Waivers and Welfare "Reform", 26 U. Mich. J.L. ReForm 741 (1993); Lucy A. Williams, The Abuse of Section 1115 Waivers: Welfare Reform in Search of a Standard, 12 Yale L. \& POL'Y ReV. 8 (1994).

19. Pub. L. No. 104-193, 110 Stat. 2105.

20. See David A. Super, The Quiet "Welfare" Revolution: Resurrecting the Food Stamp Program in the Wake of the 1996 Welfare Law, 79 N.Y.U. L. REv. 1271 (2004).

21. See generally Michele Johnson \& Kristin Ware, Medicaid Expansion by Any Other Name: Exploring the Feasibility of Expanded Access to Care in the Wake of NFIB v. Sebelius, 1 BELMONT L. REV. 119 (2014). 
work requirements but quickly backed down when Congress objected. All these waivers, however, operated within the basic frameworks of the programs: to promote self-sufficiency (in the case of cash assistance programs) and to expand access to health care (in the case of Medicaid).

Indeed, even within those purposes, these administrations refrained from using section 1115 as a substitute for legislation. Thus, either the Clinton or Obama administrations could have used section 1115 to establish near-universal health coverage regimes similar to those they instead asked Congress to enact: Although administrations customarily have insisted that waivers to be budgetneutral to the federal government, section 1115 does not require that. Doing so would have had ample legal and political precedent. The fact that neither even considered that sort of aggressive exercise of hard-power in pursuit of their highest priority demonstrates the strength of the norms of the pre-Trump administrative state. Casting aside those norms would have permanently damaged their relationships with Congress, the courts, and the civil service, which would be unthinkable for administrations seeing themselves as repeat players.

\section{B. "Work Requirements"}

Although most people assume that a "work requirement" is designed only to punish those who refuse to accept available employment, the term has changed dramatically over the years to refer to time limits on public benefits. ${ }^{22}$ For example, section 6(o) of the Food and Nutrition Act, ${ }^{23}$ which the Trump administration's policy guidance on Medicaid waivers ${ }^{24}$ praises, is entitled "work requirement" but in fact imposes a firm three-month cutoff of food assistance to unemployed recipients without any requirement that recipients unable to find private employment be offered a chance to work in exchange for further assistance. Despite generous financial incentives to do so, only a handful of states have committed to offering time-limited recipients unpaid community work opportunities as a means of maintaining eligibility for benefits. ${ }^{25}$ Further evidence that low-income people unable to find private

22. David A. Super, Opinion, 'Work Requirements' for Public Benefits Are Really Just Time Limits, L.A. Times (Jan. 15, 2018, 4:00 AM), http://www.latimes.com/opinion/op-ed/la-oesuper-work-requirements-20180115-story.html [https://perma.cc/6V83-E37L].

23. 7 U.S.C. $\$ 2015($ o) (2012).

24. See Letter From Brian Neale, supra note 9.

25. Ed Bolen et Al., Ctr. On Budget \& Policy Priorities, More Than 500,000 Adults Will LOSE SNAP BENEFITS IN 2016 AS WAIVERS EXPIRE 12 n.21 (2016), https://www.cbpp.org/research/food-assistance/more-than-500000-adults-will-lose-snap- 
employment will simply be denied aid comes from the Temporary Assistance to Needy Families (TANF) program, which was enacted on the promise that it would make recipients work for their benefits. Instead, states simply denied aid to desperately poor people. Twenty years after the 1996 welfare law created TANF, states operated only 15,007 "workfare" slots nationwide. ${ }^{26}$

Even when the state ostensibly commits itself to providing opportunities to work for those unable to find private-sector jobs, bureaucratic shortcomings cause large numbers of people to be sanctioned improperly. ${ }^{27}$ Because of fiscal crises brought on by the Great Recession, states have radically shrunk their eligibility staffs and closed numerous local offices. The highly automated and centralized agencies that remain lack the capacity to match recipients with work sites, determine qualifications for exemptions based on physical or mental limitations, sort out problems caused by lost or stolen mail, or perform the rest of the labor-intensive chores required to run work programs.

Although the various states seeking Medicaid "work requirement" waivers may have different things in mind, some states appear to intend policies like those applied to childless adult SNAP recipients: disqualifying people whether or not employment is available to them. The administration's guidance appears to invite that, and Kentucky's waiver seems to allow it.

Independent analysts and even supporters of the new requirements to find and keep employment conclude that states will not provide recipients opportunities to work in exchange for continued benefits. In analyzing a House-passed proposal to disqualify several million more unemployed SNAP recipients, the nonpartisan Congressional Budget Office (CBO) estimates that states will be operating only 110,000 unpaid work slots per month by the end of the tenth year after enactment. ${ }^{28}$ Similarly, Kentucky estimates that tens of

benefits-in-2016-as-waivers-expire\#_ftn10 [https://perma.cc/XT5Y-NQYX] (Colorado, Delaware, South Dakota, Texas, and Wisconsin). Some states have failed to keep public commitments to provide work slots for those that would be denied aid for which they are otherwise eligible.

26. David A. Super, Opinion, The New Republican Farm Bill Will Dismantle Our Programs to Feed the Needy, L.A. TIMES (May 11, 2018, 4:15 AM), http://www.latimes.com/ opinion/oped/la-oe-super-farm-bill-snap-20180511-story.html [https://perma.cc/95DE-9J5N].

27. See Hannah Katch et al., Ctr. On Budget \& Policy Priorities, Taking Medicaid Coverage Away From People not Meeting Work Requirements Will Reduce LoWInCOME FAMilies' ACCess to CARE AND WORSEN HeAlth OUtCOMES (2018), https://www.cbpp.org/sites/default/files/atoms/files/2-8-18health2.pdf [https://perma.cc/ QZK7-QS4R].

28. Dottie Rosenbaum, 6 Takeaways From CBO Estimate of House Agriculture Committee SNAP Proposals, CTR. ON BUdGet \& POL'y PRIORITIES (May 3, 2018, 5:00 PM), https://www.cbpp.org/blog/6-takeaways-from-cbo-estimate-of-house-agriculturecommittee-snap-proposals [https://perma.cc/W3U7-NP46]. 
thousands of people would lose eligibility under the Medicaid waiver that the Trump administration just approved. ${ }^{29}$ Initial data from partial implementation of Arkansas's Medicaid waiver found thousands of people disqualified. ${ }^{30}$

\section{Legal Problems With the Administration's Waivers}

The administration's waiver policy, and the individual state waivers that its Centers for Medicare and Medicaid Services (CMS) is approving, raise several serious legal problems. First, they do not seem to "promot[e] the objectives of" the Medicaid statute.

Second and related, the administration's embrace of these waivers represents a complete reversal of CMS's prior interpretation of section 1115 as not allowing these waivers because they tend to reduce Medicaid coverage.

Third, approving a waiver for Kentucky the day after the administration announced that it would approve such waivers, and others soon afterwards, ensures that the waivers did not comply with section 1115 (d)'s requirement for public hearings and engagement on proposed demonstration projects.

Fourth, these waivers are inconsistent with Congress's resolution of the question of work requirements for Medicaid, ${ }^{31}$ which allows termination of Medicaid only for adults who received cash assistance under the Temporary Assistance for Needy Families (TANF) block grant ${ }^{32}$ who "refus[e] to work," and even then, only for so long as such refusal continues. These limitations on Medicaid termination reflect clear congressional intent to limit denials of health care. ${ }^{33}$ Proposed legislation to repeal and replace the Affordable Care Act would have allowed states to impose such limitations, but that bill failed in Congress. ${ }^{34}$ Thus, instead of exploring new policies that might prove of interest

29. Judith Solomon, Ctr. on Budget \& Policy Priorities, Kentucky Waiver Will Harm MEDICAID BENEFICIARIES 2 (2018), https://www.cbpp.org/sites/default/files/atoms/files/116-18health.pdf [https://perma.cc/X638-A2JB].

30. Robin Rudowitz \& MaryBeth Musumeci, An Early Look at State Data for Medicaid Work Requirements in Arkansas, KAISER FAMILY FOUND. (Sept. 13, 2018), https://www.kff.org medicaid/issue-brief/an-early-look-at-state-data-for-medicaid-work-requirements-inarkansas/ [https://perma.cc/BWJ3-PGF9].

31. 42 U.S.C. $\$ 1396 u-1(b)(3)(A)(2012)$.

32. Id. $\$ \$ 601-15$.

33. See Camacho v. Tex. Workforce Comm'n, 408 F.3d 229 (5th Cir. 2005).

34. Thomas Kaplan \& Robert Pear, Senate Republicans Say They Will Not Vote on Health Bill, N.Y. Times (Sept. 26, 2017), https://www.nytimes.com/2017/09/26/us/politics/mcconnellobamacare-repeal-graham-cassidy-trump.html. 
to Congress, these waivers merely resuscitate policies Congress has already rejected.

Finally, the plausibility of these waivers as genuine demonstration projects is dubious: The administration's letter is gauzy about what sort of evaluation is required, and any plausible research objectives would be better served by changing the rules only for the people whom researchers wish to study, leaving the rules unchanged for a "control group" of others. If the administration approves all pending waivers, it will have changed basic eligibility policies for people representing almost 15 percent of national Medicaid enrollment, ${ }^{35}$ far more than is needed to test any research hypothesis. Because the waiver authority is limited to demonstration projects, the absence of a serious research design likely renders the waivers ultra vires. To be sure, the AFDC and Medicaid waivers earlier administrations granted crossed the statewideness threshold, drawing mixed reactions from the courts. ${ }^{36}$ Although some of these earlier waivers are open to some of the same criticisms lodged here, they came in the context of an administrative law regime in which all parties felt some obligation to moderate their actions to preserve a broad legitimating consensus. They also did not directly contradict an explicit statutory policy of Congress. ${ }^{37}$

Particular proposed waivers that the administration is entertaining show even more starkly the absence of a serious research agenda. Several proposals come from states that have refused to accept the Affordable Care Act's expansion of Medicaid. This expansion sought to ensure that families whose incomes are too low to qualify for the Act's premium tax credits could get health insurance through Medicaid. In non-expansion states, even a very modest job can render a family ineligible for health insurance, with too much income to qualify for Medicaid and too little to qualify for premium tax credits. As a result, if those states implement "work requirement" waivers, recipients

35. See May 2018 Medicaid \& CHIP Enrollment Data Highlights, MedICAID.GOv (2018), https://www.medicaid.gov/medicaid/program-information/medicaid-and-chip-enrollmentdata/report-highlights/index.html [https://perma.cc/MH4J-66QD] (providing most recent state Medicaid enrollment data); Medicaid Waiver Tracker: Which States Have Approved and Pending Section 1115 Medicaid Waivers?, KAISER FAMILY FOUND. (Aug. 29, 2018) https://www.kff.org/medicaid/issue-brief/which-states-have-approved-and-pending-section1115-medicaid-waivers/?utm_source=web\&utm_medium=trending\&utm_campaign= waivers [https://perma.cc/PWY7-XEAZ] (identifying twelve states with pending or approved work requirement waivers).

36. Compare Beno v. Shalala, 30 F.3d 1057 (9th Cir. 1994) (finding grant of statewide waiver arbitrary and capricious in absence of clear justification in record), with C.K. v. N.J. Dep't of Health \& Human Servs., 92 F.3d 171 (3d Cir. 1996) (applying a more lenient standard).

37. See, e.g., 42 U.S.C. $\$ 18091(2)(\mathrm{E})-(\mathrm{G})$ (2012) (finding that lacking insurance causes severe adverse economic and social effects). 
who do not find jobs will be sanctioned off of Medicaid and those that do find work risk being terminated for being over-income. ${ }^{38}$ When Mississippi, a nonexpansion state with some of the lowest Medicaid eligibility limits in the country, candidly stated that the purpose of its waiver was to reduce costs, CMS apparently directed the state to remove that language from its waiver application to preserve the illusion of an experiment in how to achieve Medicaid's purposes. ${ }^{39}$

\section{JUDICIAL REVIEW IN A SOFT-POWER HIATUS}

Courts justify the general regime of deference to administrative agencies by relying on the assumption that the executive branch is ordinarily seeking to adhere to the law. In such situations, the executive generally should be given latitude to act in the manner it thinks best. This approach remains viable, however, only if the courts rescind deference when the underlying assumption of good faith is violated. If the courts do not treat fidelity to law as a precondition to deference, they have little justification for retaining judicial review at all. At that point, they are not so much deferring to administrative interpretations and exercises of discretion as they are transferring legislative power from Congress to the president. This gives administrations little incentive to take the law seriously and misleads a public that naturally assumes that courts vet challenged actions before upholding them; the impression of judicial endorsement thus impedes democratic connection and risks enmeshing the courts in electoral politics.

Courts recognizing this problem might apply a variant on the formula Justice Jackson suggested in his Youngstown Sheet \& Tube v. Sawyer concurrence. ${ }^{40}$ Agencies' powers would be greatest when they demonstrated a

38. Under 42 U.S.C. $\$ 1396 r-6$, many Medicaid recipients whose incomes increase beyond their states' pre-expansion eligibility limits may receive six months, or possibly twelve months, of "transitional" coverage. Unless the recipient either loses the job or receives raises sufficient put her or him above the poverty line, however, that job would render her or him ineligible after a maximum of one year. CMS has discussed including a limited extension of transitional eligibility in "work requirement" waivers for non-expansion states, but the fundamental problem still remains: the very activity that the waivers demand endangers beneficiaries' access to health coverage.

39. Colby Itkowitz, The Health 202: Mississippi Quietly Amends Its Medicaid Work Requirement Waiver, WASH. POST: POWERPOST (Aug. 9, 2018), https://www.washington post.com/news/powerpost/paloma/the-health-202/2018/08/09/the-health-202-mississippiquietly-amends-its-medicaid-work-requirement-waiver/5b6b0fdb1b326b0207955fca/?utm _ term=.b0744b559a16 [https://perma.cc/TWN3-ZCA5].

40. 343 U.S. 579, 634-35 (1952) (Jackson, J., concurring) ("When the President acts pursuant to an express or implied authorization of Congress, his authority is at its maximum, for it 
serious effort to discern statutes' meaning and generally engage in diligent factfinding with procedural openness. The U.S. Supreme Court effectively embraced this approach in United States v. Mead Corp., which limits Chevron deference to cases in which the agency makes policy through inclusive procedures and those in which Congress demonstrated a desire for the agency's rules to have the force of law. ${ }^{41}$

Shared structural norms are at least as important as specific legal rules in establishing the rule of law in the administrative state because legal rules are written against the background of the then-prevailing normative ideology. Dangers of legal rules being misused that are possible only under other normative systems are either not considered in the legislative process or, if raised at all, are dismissed as paranoid.

We have never previously seen the systemic rejection of the administrative state's structural consensus that characterizes the current administration. The closest analogies come from individual agencies' occasional efforts to disregard the usual checks and balances. Perhaps the best-known of these is the Social Security Disability Insurance crisis of the early and mid-1980s. There, the Reagan administration set out to purge huge numbers of people from the rolls despite serious demonstrable impediments to work. It sought to leverage the deferential standard of review for the Social Security Administration's (SSA's) decisions to cover denials and terminations motivated far more by fiscal concerns than by a serious evaluation of the evidence. ${ }^{42}$ As this became apparent, the courts, including the Supreme Court, came to believe the SSA was not making a sincere effort to administer the existing legal regime. ${ }^{43}$ As a result, courts developed a range of extraordinary deference-rejecting doctrines. ${ }^{44}$ Perhaps the most striking example of this was in Bowen v. City of New York, with the Supreme Court finding that SSA had adopted secret lawless policies rendering the formal review process all but meaningless. ${ }^{45}$ These extraordinary measures did not metastasize to damage the rest of administrative law, and indeed they were largely absent from SSDI law just a few years later once the agency discontinued its defiance.

includes all that he possesses in his own right plus all that Congress can delegate." (footnote omitted)).

41. 533 U.S. 218 (2001).

42. See David A. Super, Public Welfare LaW 1202-06 (2017) (describing the Reagan purge and the backlash it generated).

43. See, e.g., Schisler v. Bowen, 851 F.2d 43, 44-45 (2d Cir. 1988); Hidalgo v. Bowen, 822 F.2d 294, 298 (2d Cir. 1987); Wier ex rel. Wier v. Heckler, 734 F.2d 955, 956-57 (3d Cir. 1984).

44. See, e.g., Spencer v. Bowen, 798 F.2d 275, 278 (8th Cir. 1986).

45. 476 U.S. 467 (1986). 
On a smaller scale, the D.C. Circuit in the late 1990s and early 2000s came to regard the Bureau of Indian Affairs' treatment of Native American trust accounts as utterly lawless and imposed startlingly intrusive remedial measures on the entire Interior Department. ${ }^{46}$ Many, although not all, federal circuits regarded the Bush administration's restructuring of the Board of Immigration Appeals as producing systematically lawless decisions and embraced special presumptions against agency regularity. ${ }^{47}$ Each of these episodes saw a sudden collapse of longstanding regimes of deference and witnessed dramatic, if relatively short-lived, expansions in the scope of remedies courts were willing to employ. As the agencies disregarded the soft-power constraints from other players in administrative law, the courts responded with hard power of their own.

This Part examines three tools available to courts to restrain potentially lawless agencies. It argues that these tools merit modification during periods of systematic disregard for the administrative state's norms.

\section{A. The Anti-Delegation Doctrine}

In a pair of cases decided in 1935, the Supreme Court held that Congress may not delegate effective lawmaking power to the executive branch without meaningful standards that constrain the exercise of that power. ${ }^{48}$ The Court has not explicitly invoked the anti-delegation doctrine to decide a case since 1935 , but it has declined numerous opportunities to dispense with it altogether. Justices at both ${ }^{49}$ ends of the ideological spectrum have invoked it in separate opinions. Justice Rehnquist provided the fifth vote for invalidating an Occupational Safety and Health Administration (OSHA) regulation with a concurrence concluding that OSHA's statute violated the anti-delegation doctrine..$^{50}$

The Court has kept this doctrine in reserve for addressing a serious emergency. That emergency has arrived. The courts should recognize that the current administration's reading of section 1115 as authorizing it to disregard statutory requirements with which it disagrees at least raises serious

46. See, e.g., Cobell v. Norton, 240 F.3d 1081 (D.C. Cir. 2001).

47. See, e.g., Benslimane v. Gonzales, 430 F.3d 828 (7th Cir. 2005).

48. Schechter Poultry Corp. v. United States, 295 U.S. 495 (1935); Panama Refining Co. v. Ryan, 293 U.S. 388 (1935)

49. See, e.g., McGautha v. California, 402 U.S. 183, 271-80 (1971) (Brennan, J., dissenting).

50. See Indus. Union Dep't v. Am. Petroleum Inst., 448 U.S. 607, 671-88 (1980) (Rehnquist, J., concurring in the result). 
constitutional questions ${ }^{51}$ about whether section 1115 is an unconstitutional delegation of the power to make law..$^{52}$ Accordingly, the courts should interpret section 1115's requirements strictly to require good-faith demonstration projects limited to the scope necessary to test a plausible research hypothesis.

For the Court not to invoke the doctrine in these circumstances would raise the question of whether it could ever be used at all: If the current situation is not sufficiently problematic to justify invoking these reserved judicial powers, then situations that would justify invoking them must be so spectacularly rare as to undercut these powers' very justification. Indeed, if the anti-delegation doctrine is regarded as one that no rational court would invoke, its only role will be to empower some possible future irrational Court.

Formally, the disposition of anti-delegation claims has depended on whether the challenged statutory standard constrains executive action sufficiently as to avoid a delegation of legislative powers. ${ }^{53}$ Given the remarkable gauziness of the statutory provisions the courts have upheld against challenges under the anti-delegation doctrine, the unspoken question is whether adherence to the normative administrative law consensus combined with these statutory limits suffices to make executive activity effectively nonlegislative. Thus, for example, section 1115's authority only effectively constrains administrative action if "promoting the objectives of" the Medicaid statute is a standard with meaning: If an administration feels free to substitute its own purposes for those of the statute then section 1115 becomes every bit as open-ended a license to rewrite duly-enacted statutes as was the line-item veto struck down in Clinton v. City of New York. ${ }^{54}$

Many battles over the anti-delegation doctrine have involved systemically important statutes: wage-and-price controls for the whole economy, ${ }^{55}$ the authority of major agencies like the Environmental Protection Agency (EPA) $)^{56}$ and $\mathrm{OSHA}^{57}$ to act, sentencing in all federal criminal cases, ${ }^{58}$ and so forth. Yet some of the most sweeping delegations occur in numerous "safety valve"

51. See, e.g., NLRB v. Catholic Bishop of Chi., 440 U.S. 490 (1979) (requiring courts to adopt plausible readings of statutes that avoid substantial constitutional questions).

52. See Clinton v. City of New York, 524 U.S. 417 (1998) (striking down statute authorizing president to designate provisions of appropriations and tax law that would not be followed).

53. See, e.g., Yakus v. United States, 321 U.S. 414 (1944); Amalgamated Meat Cutters \& Butcher Workmen v. Connally, 337 F. Supp. 737 (D.D.C. 1971).

54. 524 U.S. 417, 448-49 (1998).

55. See generally Yakus, 321 U.S. at 414; Amalgamated Meat Cutters, 337 F. Supp. 737.

56. Whitman v. Am. Trucking Ass'ns, Inc., 531 U.S. 457 (2001).

57. Industrial Union Department, 448 U.S. at 687 (Rehnquist, J., concurring in the result).

58. Mistretta v. United States, 488 U.S. 361, 412 (1989). 
provisions of federal statutes that grant sweeping powers to executive agencies for use only in very limited circumstances, such as natural disasters, ${ }^{59}$ focused research projects, ${ }^{60}$ unanticipated trade conflicts, ${ }^{61}$ or threats to national security. ${ }^{62}$ These provisions' narrow substantive scope allows both Congress and the courts to worry less about administrative overreach. These provisions can serve valuable purposes at the frontiers of governance, where Congress's capacity to anticipate needs is at its weakest.

These provisions' continued viability, however, depends on ensuring that they remain limited in scope. Their very open-textured character could allow administrators to transform them into Trojan horses, radically redirecting substantive law without congressional approval. When administrators abuse limited-purpose grants of authority in that way, they prompt future Congresses to rethink the wisdom of enacting such broad legislation and thus threaten the sustainability of these safety valve provisions. These safety valve provisions' benefits would also be lost if a court invoked the anti-delegation doctrine to invalidate them outright.

Increasingly, however, the Court has sought to assuage the concerns underlying the anti-delegation doctrine through less absolute means. It has restricted who may exercise particularly broad, potentially problematic delegated powers. ${ }^{63}$ It has read other constitutional provisions formally to block some sweeping delegations ${ }^{64}$ and make others politically uncomfortable by denying Congress any control in the execution of laws other than by enacting new statutes. ${ }^{65}$ And although the Court has said in dicta that agencies cannot save delegations with limiting constructions, ${ }^{66}$ the courts can certainly do so under the doctrine of constitutional avoidance. ${ }^{67}$ The Court has constrained delegations to prosecutors with various plain-statement rules; ${ }^{68}$ it could do so for executive officials more generally.

Under this latter approach, the Court could require a plain statement in the relevant statute that executive discretion is intended to reach the outer

59. 7 U.S.C. $\$ 2014(\mathrm{~h})(2012)$.

60. Id. $\$ 2026(\mathrm{~b})$.

61. Fed. Energy Admin. v. Algonquin SNG, Inc., 426 U.S. 548, 550 (1976).

62. Holder v. Humanitarian Law Project, 561 U.S. 1, 20 (2010); United States v. Hammoud, 381 F.3d 316, 331 (4th Cir. 2004).

63. Hampton v. Mow Sun Wong, 426 U.S. 88, 116 (1976); Kent v. Dulles, 357 U.S. 116, 129 (1958).

64. Clinton v. City of New York, 524 U.S. 417, 448-49 (1998) (invalidating line-item veto).

65. See, e.g., Bowsher v. Synar. 478 U.S. 714 (1986) (disallowing role for congressional appointee); INS v. Chadha, 462 U.S. 919, 954-55 (1983) (disallowing legislative veto).

66. See Whitman v. Am. Trucking Ass'ns, Inc., 531 U.S. 457, 472 (2001).

67. See NLRB v. Catholic Bishop of Chi., 440 U.S. 490, 507 (1979).

68. United States v. Wagner, 382 F.3d 598, 610 (6th Cir. 2004). 
limits of its constitutionally permissible powers before concluding that a sweeping delegation was intended. Absent such legislative direction, the courts would interpret the statutory limits on agency discretion fairly, rather than deferentially. Thus, for example, the courts would actually seek to determine the purposes of Title XIX of the Social Security Act, and whether Medicaid work requirement waivers plausibly advanced those purposes, rather than assuming that that vague language was intended to empower the agency.

In these cases, judicial intervention paradoxically increases executive flexibility in the long term by obviating the need for Congress to purge statutes of the authority being abused. Courts often vindicate exercises of executive power in order to keep free the hands of future administrations rather than because of any particular merit in the action at hand. Here, striking down abuses of these sweeping delegations can provide the reassurance for Congress to continue granting such powers in the future. Congress can only safely include them in statutes if it has confidence that executive officials will exercise this power with restraint and that, when they utterly fail to do so, courts will insist. The failure to do so will cause many of them to be withdrawn over time, which does not serve the public interest well at all. Thus, a judicial check on abuses of delegated executive authority will, in the middle and long term, actually expand executive power, or at least legitimate exercises of that power.

If the courts ignore blatant attempts to reverse congressional decisions through section 1115, future Congresses are likely to feel the need to repeal or radically restrict that section in order to make their judgments stick. Section 1115 's complete demise would undermine its core purpose: evidence-based policy development. A more constructive approach would be for courts to invoke constitutional avoidance to interpret the statutory requirements for such waivers-that they be actual demonstration projects and that they be consistent with the purposes of the Social Security Act-as precluding attempts at executive nullification of congressional choices. This would lead to disallowing the waivers imposing new work conditions on Medicaid eligibility on the grounds that they effectively reject decisions Congress took in 1996 and 2010 and seek to revive legislation defeated in 2017. In the same vein, courts invoking constitutional avoidance could disallow these waivers because they represent efforts to change policy on a broad basis rather than a serious effort to learn about new policies' impact through discrete, rigorous, experiments.

The alternative-deferential acceptance of executive authority to rewrite statutes-is as unsustainable as it is subversive of the separation of powers. If President Trump can nullify congressional decisions to extend Medicaid benefits, future presidents could override limits Congress has decided to 
impose on eligibility for benefits. A wide range of factors-from safe housing to good nutrition to education - have been found to improve health outcomes. If the current waivers pass muster, no principled basis would exist to stop future administrations from allowing states to expand food assistance or housing programs with Medicaid funds under section 1115. Broad deference to executive actions under authority as sweeping as section 1115 could readily lead to chaos, with wild policy swings each time the White House changes hands.

Courts using constitutional avoidance and the anti-delegation doctrine to rein in section 1115 waivers would also have the salutary effect of inducing Congress to play a more active role in considering and making policy. This likely would result in executive moves being either ratified or rejected. An administration seeking to test policies that fundamentally alter a program's course would have to seek congressional approval, perhaps in the program's annual appropriations act. This would be in keeping with Justice Jackson's admonition in Youngstown Sheet \& Tube v. Sawyer ${ }^{69}$ that the extent of executive power should depend on the extent of congressional support.

\section{B. Substantive Review}

In exercising substantive review of radical waivers under section 1115, the courts should recognize that familiar doctrines of deference are ill-suited to the task. Ordinarily, agencies' interpretations of the statutes they are charged with implementing often receive strong deference from courts, and agencies' exercises of delegated discretion are reversed only if found to be arbitrary and capricious or abuses of discretion. These doctrines' premises are that the executive is permitted to adapt the legislative regime to different priorities and points of emphasis, but that it is not permitted to break with the regime it inherited, absent new legislation. This is sometimes a difficult line to draw.

No such difficulty exists, however, when an administration makes a major, high-profile effort to enact legislation, repeatedly fails, and then exploits a delegation of exception-making authority to make many of the same changes via administrative law. No deference is appropriate when an administration seeks to accomplish through administrative reinterpretation what Congress refused to do through legislative amendment. Thus, for example, had President Clinton responded to the defeat of his health care reform proposal with new, expansive interpretations of the Medicaid statute-or section 1115-to

69. 343 U.S. $579,634-38$ (1952). 
accomplish the same thing, courts should have shown him no deference. Similarly, when the current administration responded to the defeat of its legislation to reduce eligibility for Medicaid and health care premium subsidies by reversing longstanding interpretations to achieve the same thing, the courts should recognize this as an attempt at overturning rather than interpreting the will of Congress. The administration's numerous actions, many of questionable legality ${ }^{70}$ with the avowed purpose of impeding implementation of the Affordable Care Act, confirm that restricting health care subsidies, notwithstanding Congress's refusal to repeal that Act, is its objective, not sincere policy research.

As a threshold matter, Chevron deference-the doctrine that when a statute does not address an issue, the courts should defer to any "reasonable" agency interpretation-should not even come up with regard to these interpretations of section 1115, because the Medicaid-waiver approval process is far less deliberative or inclusive than those that the Court has said merit Chevron deference. ${ }^{71}$ In United States v. Mead Corp., the Court limited this heightened deference to cases of express or implied delegations of lawmaking authority to administrative agencies. ${ }^{72}$ "It is fair to assume generally that Congress contemplates administrative action with the effect of law when it provides for a relatively formal administrative procedure tending to foster the fairness and deliberation that should underlie a pronouncement of such force." ${ }^{73}$ The Court identified these as formal adjudication, formal rulemaking, and notice-and-comment rulemaking, all of which provide for extensive participation by the affected parties in shaping the agency's statutory interpretation. The Department of Health and Human Services has never promulgated substantive rules setting out its understanding of what section 1115 allows, and the process by which it makes those decisions ad hoc on particular waivers is far less formal or inclusive than those the Court recognized as worthy of broad deference.

Even if Chevron did apply, these waivers would not merit deference. The Court sometimes justifies Chevron deference by arguing that Congress likely intended for the agency, rather than the courts, to resolve ambiguities. ${ }^{74}$ This likely is true when the agency in question is playing the kind of role Congress

70. Nicholas Bagley \& Abbe R. Gluck, Trump’s Sabotage of Obamacare Is Illegal, N.Y. TimEs (Aug. 14, 2018), https://www.nytimes.com/2018/08/14/opinion/trump-obamacare-illegal.html.

71. Chevron, U.S.A., Inc. v. NRDC, 467 U.S. 837 (1984).

72. 533 U.S. 218, 229-31 (2001).

73. Id. at 230 (footnote omitted).

74. Id. at 227 . 
could plausibly have envisioned. Congress knows that some future administrations will be of the opposite party and, when choosing ambiguous terms in legislation, surely takes into account the power it is granting to future administrations with divergent policy preferences. Congresses cannot so easily, however, be charged with the knowledge that a future administration would operate wholly outside the long-term structural consensus. Many of the administrative state's implicit checks and balances operate only over an extended period, for instance when agencies refrain from indulging their shortterm preferences in order to maintain credibility in the future. When an administration demonstrates a short-termer's attitude that effectively frees it from those constraints, courts seeking to honor Congress's expectations must apply more searching review to replace those constraints. Similarly, just as one basis for deferring to exercises of administrative discretion is the belief that they are informed by superior capacities for fact-finding, when fact-finding is found to be dishonest and distorted, exercises of interpretive discretion, even those not explicitly dependent on that fact-finding, should be questioned.

The simplest basis for scrutinizing section 1115 waivers is to determine whether they are "likely to assist in promoting the objectives of" the Medicaid statute. $^{75}$ Although courts operating within the post-New Deal structural consensus commonly shy away from seeking to ascertain the objectives of legislation, ${ }^{76}$ here the task is not difficult. The administration claims that working promotes health and that the statute's purpose is improving health. Neither of these assertions is straightforwardly true. Medicaid's purpose is expanding health insurance coverage, which seems contradictory to a plan expected to deny coverage to tens of thousands of people in Kentucky alone. As amended by the Affordable Care Act, Medicaid is particularly focused on achieving as nearly universal coverage as possible to minimize the inefficiencies that result when hospitals and others provide large amounts of care for which they are not compensated. Increasing the ranks of the uninsured certainly does not accomplish that.

In addition, routine application of tools of statutory construction-a prerequisite to Chevron analysis ${ }^{77}$-also suggests that section 1115 cannot be interpreted to support the new waivers. Section 1931 of the Medicaid statute shows that Congress knows how to craft work requirements and has chosen to do so in only a very limited way. Legislative silence ordinarily is entitled to little

75. $\quad 42$ U.S.C. $\$ 1315(a)(2012)$.

76. See, e.g., Nicholas Bagley, Are Medicaid Work Requirements Legal?, 319 J. Am. MED. Ass'N 763 (2018) (approaching these questions within the post-New Deal consensus).

77. Chevron, U.S.A., Inc. v. NRDC, Inc., 467 U.S. 837, 843 n.9 (1984). 
weight because it has no recognized standing within the terms of the U.S. Constitution and because any number of factors can lead to a bill's failure (including, most commonly, the legislature's failure to focus fully). The defeat of multiple efforts to repeal and replace the Affordable Care Act is not mere ordinary legislative silence: These efforts had extreme salience, and they were clearly defeated on their merits. This makes clear that the administration is acting at the nadir of its power, in opposition to past Congresses that enacted and amended the Medicaid statute over the years, and with no support from the current Congress that chose not to disturb that statute. Thus, "employing traditional tools of statutory construction," courts may discern a congressional intent inconsistent with the current administration's reading of section 1115 .

Doctrines for reviewing exercises of executive discretion also demonstrate how anomalous the new Medicaid "work requirement" waivers are. Even absent the systemic failures we are now experiencing, Citizens to Preserve Overton Park, Inc. v. Volpe $e^{79}$ encourages courts to infer purposes from legislative text and to override administrative actions that either consider illegitimate factors or disregard mandatory ones. This approach is especially apt for applying a statute that specifically requires adherence to its "objectives." The administration's desire to reverse its congressional defeat is about as illicit a purpose as one can readily imagine; its failure to consider the individual and systemic consequences of increasing the ranks of the uninsured is similarly unacceptable under Overton Park. This administration's 180-degree reversal of its predecessors' determination of the appropriateness of waivers of this kind also runs afoul of the principle that changes in direction require clear explanations of what has changed and why the evidence relied upon in prior determinations should not dictate continuing the prior policy. ${ }^{80}$ And the absence of any explanation why these "demonstration projects" need to operate statewide, rather than with discrete treatment and control groups, is just the sort of irrationality that courts often find arbitrary and capricious. Even before the current administration, and even on issues not recently addressed by

78. Id.

79. 401 U.S. 402 (1971).

80. See Motor Vehicle Mfrs. Ass'n v. State Farm Mutual Auto. Ins. Co., 463 U.S. 29 (1983). FCC v. Fox Television Stations, 556 U.S. 502 (2009), disclaims any substantive preference for the prior rule, but it does not dispense with agencies' obligations to explain their analysis of the evidence and policy considerations supporting the policies they reverse. 
Congress, courts have occasionally invalidated waivers when serious policy research did not appear to be the motivating factor. ${ }^{81}$

Courts weighing section 1115 waivers can learn from their predecessors' response to the Reagan administration's purge of the Social Security disability rolls in the 1980s. The "substantial evidence" standard of review applicable to those cases is little different from the "arbitrary and capricious" standard courts will apply to waivers. Just as the courts of the 1980s concluded that no termination of benefits was supported by substantial evidence unless the agency showed either that the initial grant of benefits was erroneous or that the recipient's medical condition had improved significantly, ${ }^{82}$ and that medical conclusions contrary to the opinion of the claimant's treating physician needed solid support, ${ }^{83}$ today's courts could establish similar elaborations of what is "arbitrary and capricious" in the waiver context. For example, they could recognize a presumption that waivers are arbitrary and capricious if they purport to test policies that Congress has explicitly rejected by statute or if they remove congressionally-conferred benefits statewide rather than for a discrete treatment group.

\section{Procedural Review}

Procedural review of agencies' actions balances the agency's substantive goals with concern for fair and accurate processes. Under ordinary circumstances, courts assume that agencies can readily reconcile these goals. When, however, the substantive needs are exceptionally strong, they may overwhelm procedural concerns such as the need for a pre-deprivation hearing ${ }^{84}$ or allowing the public time to adjust before a new regulation takes effect. Thus, when affected persons have sued to set aside agencies' actions for failure to comply with the Administrative Procedure Act, other statutory or regulatory procedural requirements, or procedural due process, the Court has been willing to subordinate those procedural concerns to genuine public

81. Newton-Nations v Betlach, 660 F.3d 370 (9th Cir. 2011); Beno v Shalala, 30 F.3d 1057 (9th Cir. 1994).

82. See, e.g., Simpson v. Schweiker, 691 F.2d 966, 969 (11th Cir. 1982).

83. See, e.g., Pratt v. Sullivan, 956 F.2d 830 (8th Cir. 1992).

84. See, e.g., Ewing v. Mytinger \& Casselberry, Inc., 339 U.S. 594, 598-600 (1950) (allowing seizure of allegedly misbranded dietary supplements prior to a hearing); Fahey v. Mallonee, 332 U.S. 245, 250-54 (1947) (allowing merger of insolvent financial institution without a pre-deprivation hearing because of the danger of further losses during any delay); cf., Mitchell v. W.T. Grant Co., 416 U.S. 600, 607-09 (1974) (finding danger to disputed property justifies denial of pre-deprivation hearing). 
emergencies, especially when it believes that the agency has a high likelihood of being correct on the merits. ${ }^{85}$

Although less explicitly established, the reverse should also be true: When procedural concerns are especially severe, they should overwhelm the usual deference to the agency's choice of substantive goals. ${ }^{86}$ For example, although Vermont Yankee ${ }^{87}$ generally prohibits courts from mandating additional steps in notice-and-comment rulemaking beyond those specified in section 553 of the Administrative Procedure Act, it does make an exception for extraordinary circumstances. ${ }^{88}$ One such circumstance is compelling evidence that the agency is not acting in good faith, as when an agency seeks to override legislation it disfavors through the regulatory process.

Vermont Yankee's general prohibition of judicially-crafted additional procedures does not apply to judicial review of the Medicaid work requirement waivers, because the agency has altogether declined to engage in notice-andcomment rulemaking to promulgate its new Medicaid eligibility policy. Moreover, Congress has established additional procedural requirements for policymaking through section 1115 . Courts can and should determine whether waivers were issued in compliance with these requirements as well as whether additional development of the record is needed to determine whether a waiver meets section 1115's substantive requirements.

Separately, $H B O$ v. $F C C^{89}$ held that, when the volume and intensity of ex parte communications render the formal agency record illusory, the Administrative Procedure Act's judicial review provisions allow courts to demand that the agency give a full public airing of concerns. As one waiver was approved only one day after the administration announced its new policy, and others followed soon thereafter, the formal record of these actions obviously does not tell the real story. Reviewing courts should thus vacate waivers granted under these conditions and direct the agency to reconsider its decisions through new proceedings that produce a record actually reflecting what the agency is considering. At a minimum, courts should not confine the record on

85. See, e.g., Alcaraz v. Block, 746 F.2d 593, 611-13 (9th Cir. 1984) (allowing agency to dispense with notice-and-comment rulemaking to implement budget-cutting legislation timely); Phila. Citizens in Action v. Schweiker, 669 F.2d 877, 882-85 (3d Cir. 1982) (same).

86. To do otherwise would effectively concede that substantive needs are inherently superior to procedural ones, which makes little sense as a matter of either the APA's text or sensible norms.

87. Vt. Yankee Nuclear Power Corp. v. NRDC, Inc., 435 U.S. 519, 524 (1978).

88. Id. at 542 .

89. 567 F.2d 9 (D.C. Cir. 1977). 
review to the items formally presented to the agency when other information and motivations obviously drove the rapid decisions.

The substantive needs of agencies must be constantly balanced with the mandate of procedural regularity. Courts recognize that exceptional substantive needs sometimes require subjugating procedural ones. The reverse should also be true: When procedural irregularities are severe, they should override routine, nonemergency substantive objectives.

\section{The CIVIL SERVICE IN A SOFT-POWER Hiatus}

As Jon Michaels has powerfully demonstrated, in the administrative state's implicit separation of powers, career civil servants hold responsibilities closely analogous to those of the courts under the constitutional separation of powers. ${ }^{90}$ With protected tenure, career civil servants are expected to uphold the rule of law and to protect systemic interests that transcend the agenda of any particular administration. Indeed, much of their power derives from the courts: Not only do the courts enforce civil service laws to shield them from politically motivated dismissals, but the standard of review strongly favors administrative actions crafted by career bureaucrats over those thrown together by political appointees. When career bureaucrats write thorough notices of proposed rulemaking and meticulously respond to all comments received, courts commonly find adherence to the Administrative Procedure Act's noticeand-comment requirements. More generally, bureaucrats are well positioned to amass the combination of data and arguments that persuade courts that decisions were not arbitrary and capricious. ${ }^{91}$

In ordinary times, this process is constructive: Input from civil society and norms of legality filter through civil servants to produce decisions within the general terms set out by political appointees. In the current environment, however, political appointees are driving an ideological agenda that respects neither Congress's legislative choices nor the input of civil society. For bureaucrats to perform their usual roles in this environment would not be to

90. See Jon D. Michaels, Constitutional Coup: Privatization's Threat to the American REPUBLIC 60-61 (2017).

91. In Michaels's framing, civil society's role in the administrative separation of powers is analogous to the role of Congress in the constitutional separation of powers representing the diversity of social opinion on a given topic. Most directly, political appointees in administrative agencies mirror the role of the president in the constitutional system, initiating policy decisionmaking and focusing debates with specific proposals. Just as civil servants derive much of their power from the support of the courts, civil society's influence comes at least in part from its ability to mobilize factions within Congress, and political appointees derive their power from the president's support. 
develop public policy but rather to obscure the processes behind it. Giving the appearance that public comments were considered when in fact they were not, or that expertise shaped a decision when it did not, creates a false record that can only mislead courts and, ultimately, the electorate. ${ }^{92}$ Not only are bureaucrats not required to do this, but their oaths to uphold the Constitution and laws of the United States forbid them from doing so. ${ }^{93}$

The Rules of Professional Responsibility provide an appropriate guide to the obligations of civil servants, even non-lawyers. ${ }^{94}$ This metaphor, of course, requires a judgment about who should be regarded as the "client," but civil servants' oaths are to the United States, not to their current political officials. Even to the extent that those officials are seen as having authority to say what the goals of the government are, civil servants, like attorneys, may pursue their clients' goals only through lawful means. To give a false aura of deliberation ${ }^{95}$ to politically preordained decisions is tantamount to engaging in a coverup.

In attempting to honor their obligations to the nation as a whole, rather than their current political masters, civil servants should consider several concrete steps, each entirely legal. First and most obviously, they should maintain scrupulous honesty in everything they write, both for internal and external consumption. If they do not believe that the research supports a particular proposition, they should not write that it does. This does not mean that civil servants need to be abrasive or obstructionist or that they need constantly to oppose political appointees' decisions. But civil servants should not pretend that such decisions reflect the views of career staff or that they were driven by factors that they were not. This honesty is a service to the political appointees-keeping them from losing track of which decisions were political calls and which were genuine expertise-driven policies that they can expect career staff to defend to their successors in future administrations.

92. See generally Heidi Kitrosser, The Accountable Executive, 93 MINN. L. REV. 1741 (2009).

93. Cf. Jennifer L. Mascott, Who Are "Officers of the United States"?, 70 Stan. L. REv. 443 (2018) (arguing that many bureaucrats should be understood as officers of the U.S.).

94. Cf. Jennifer Nou, Taming the Shallow State, YALE J. on Reg. Notice \& COMMENT (Feb. 28, 2017), http://yalejreg.com/nc/taming-the-shallow-state-by-jennifer-nou [https://perma.ccl Z8RQ$\mathrm{MD} 2 \mathrm{~B}]$ (discussing limits to bureaucratic resistance).

95. For example, if a state makes clear that the purpose of its waiver request is to save money rather than to advance the purposes of the Act, counseling the state to obscure that goal in its waiver request misleads potential public commenters, the courts, and other decisionmakers. The public record suggests that this may have happened at least with respect to Mississippi's waiver request. See supra notes 38-39 and accompanying text. Similarly, when career staff that lack the authority to reject a waiver application write rebuttals to novel public comments opposing those waivers without bringing those comments to the attention of the actual decisionmakers, the rebuttals are likely to mislead reviewing courts into believing that those are the reasons the comments were rejected. 
Second, in preparing analyses of comments received from the public, civil servants should resist the common impulse to lump together similar but nonidentical comments or to capture only the highpoints of comments making many arguments. Congress and reviewing courts should be able to rely on the accuracy and completeness of comment summaries prepared by impartial civil servants.

Third, civil servants should be entirely honest in describing why public comments are being disregarded. If political appointees have determined that the goal of transforming Medicaid should override any contrary concerns, civil servants preparing responses to public comments should simply say as much, rather than inventing objections and explanations that did not, in fact, influence the decision. Although both expertise and political decisions will, at times, merit deference, Congress and reviewing courts should be able to tell the difference between the two.

Fourth, civil servants should decline to cut legally mandated corners to comply with artificial deadlines set by political officials. Managers naturally should be responsive to political appointees in reassigning additional staff to high-priority projects, and individual civil servants should work conscientiously on their assigned projects, but neither are responsible for the unrealistic expectations of political appointees who may have little experience with the machinery of government. Career managers should be candid with political appointees about how long various tasks will require, but if political appointees disregard that advice, then the managers cannot be held responsible for failing to completely execute all tasks before the administration leaves office. If political appointees order civil servants to move forward without completing the required steps, the career staff should obey but should not participate in any effort to mislead readers into believing that those steps were performed.

Finally, if anything they write is edited without their agreement to misrepresent their views, they should protest immediately and formally. Political appointees are entitled to attempt to make policy on their own, but they are not entitled to pass their views off as those of career civil servants.

All of these are sound principles even in ordinary times when administrative law is operating within the post-New Deal consensus. These steps take on new, vital meaning, however, when the longstanding norms of administrative law are being disregarded. In such circumstances, civil servants' participation will matter far more because political appointees operating outside the New Deal consensus may feel they cannot afford to be candid about what they are doing without losing judicial and congressional deference. 
In the particular case of Medicaid waivers to disqualify unemployed persons, the courts' belief that these are genuine demonstration projects is crucial to those waivers being upheld. A part of justifying that belief is designing credible evaluations. If a civil servant believes that these are not true demonstration projects because the officials approving them are not seeking to test new policy concepts but rather to change the law without involving Congress, then presenting a superficially plausible evaluation is essentially a coverup of the true nature of these actions. Thus, for example, if civil servants believe useful policy information cannot be obtained without studying a control group for comparison, they should not write rationales for omitting one. If they believe that little useful policy information can be obtained by applying the demonstration statewide, they should not manufacture reasons why statewideness supports research goals. ${ }^{96}$ And if civil servants believe that an evaluation is failing to measure important health outcomes, they should refuse to sign off on any statement to the contrary.

\section{CONCLUSION}

At some point, this period of bare-knuckles, hard-power administrative law will end. It is too disruptive and chaotic to serve even the deregulatory interests that helped set it in motion. The same willful disdain that has caused this administration to cast aside the post-New Deal consensus that supported the soft-power regime of administrative law has caused it to take numerous other actions that have alienated voters. Moreover, the electorate's disposition is too conservative-and too wedded to social niceties - to tolerate this for very long. To be sure, the tumult of the Trump Era could give way to a more buttoned-down, organized pursuit of the same goals under a Mike Pence or a Paul Ryan. More likely, however, the next president and Congress will resubscribe to the post-New Deal structural consensus, whatever their substantive goals.

The response courts and civil servants adopt to the current conditions should provide as little impediment as possible to the revival of efficient administrative management. The approach advocated here-an explicitly temporary suspension of deference to political leaders who disregard their roles in the structural consensus-is most conducive to that goal. A weaker response that ignores the lawlessness of the current administration could well lead to a

96. See Beno v Shalala, 30 F.3d 1057 (9th Cir. 1994) (striking down demonstration project supposedly testing the work incentives of benefit cuts because the state did not expect many of those subject to the project to work). 
search for perpetrators and collaborators once this moment is passed. The President's repeated embraces of a "Lock her up!" sentiment does not augur well for persuading his opponents to refrain from prosecuting all those officials implicated criminally in scandals. They also may seek to purge civil servants who appear to have been selected by these political appointees. The resulting upheaval would be messy, expensive, and sometimes unjust. As noted above, a perception that the judiciary acquiesced in executive lawlessness would undermine both the courts' reputation as protectors of the rule of law and the rationale for judicial review.

The goal, instead, should be the modern equivalent of the Act of Indemnity and Oblivion that Charles II enacted in $1660 .{ }^{97}$ That statute paved the way for the restoration of the English monarchy after the Puritan Revolution had deposed and killed Charles's father, King Charles I. It struck a balance between civic peace and erasing the illegitimate excesses of the Puritans' Commonwealth, voiding much of the law enacted during the interregnum but forgoing retribution against any but the bloodiest Cromwellians.

Conversely, a wholesale rejection of deferential judicial review not specifically tied to the current administration's abrogation of the post-New Deal consensus would impede its reestablishment once the emergency has passed. If courts justify their refusal to afford deference as a broader rethinking of the role of judicial review, they may have difficulty finding rationales for walking back their anti-deference rulings under more law-abiding administrations in the future. Ironically, announcing a generically more intrusive form of judicial review now could slow a restoration regime's reversal of lawless actions undertaken during this period.

Available precedent, albeit limited, offers hope that a limited departure from deferential review is eminently reversible once the emergency passes. After the courts savaged President Reagan's Social Security Administration for disregarding substantive and procedural norms in its administration of disability benefits, when a new commissioner took office and explicitly committed the agency to adhering to the law, the courts rapidly receded into their accustomed posture. Cases that would have prompted angry reversals a few years earlier received minimalist affirmances from the same courts. If anything, having trounced SSA during the period when it was behaving lawlessly, many judges seemed eager to mend fences with the new, more thoughtful agency.

97. J.P. Kenyon, The STUART CONSTITUTION 1603-1688: DoCumentS AND COMMENTARY 365$71(1966)$ 
Striking down the Medicaid "work requirement" waivers, as the first federal court to consider one has done, ${ }^{98}$ need not destroy future administrations' ability to conduct serious demonstrations of new policies that might enhance Medicaid's performance in any number of ways. Indeed, by removing the need for a future Congress to repeal section 1115, courts can preserve and strengthen the authority for genuine policy research.

As this administration proceeds, the issues this Article addresses take on increasing salience far beyond Medicaid waivers under section 1115. For example, the Trump administration is relying on a similar "safety-valve" provision in trade legislation ${ }^{99}$ to launch a massive trade war. Its claim that our national security is impaired by importing steel and aluminum from some of our closest allies is no more credible than its assertion that its Medicaid waivers are genuine demonstration projects. In both instances, the administration's public statements make clear that its actual purposes are entirely different from those that allow invocation of the safety valve. If the courts sustain disingenuous invocations of the national security exception to our trade laws, the only way Congress will be able to prevent a future president from unilaterally launching a massive and destructive trade war will be to repeal those sections. That, however, will leave this country without the means to protect its national security against genuine threats from our adversaries.

Our system encourages courts and civil servants to exercise restraint, saving their powers and credibility for a rainy day. Today, it is raining.

98. Stewart v. Azar, No. 18-152 (JEB), 2018 WL 3203384 (D.D.C. June 29, 2018).

99. 19 U.S.C. $\$ 1862(2012)$. 